\title{
A tribute to John Walter Thomson (1913-2009)
}

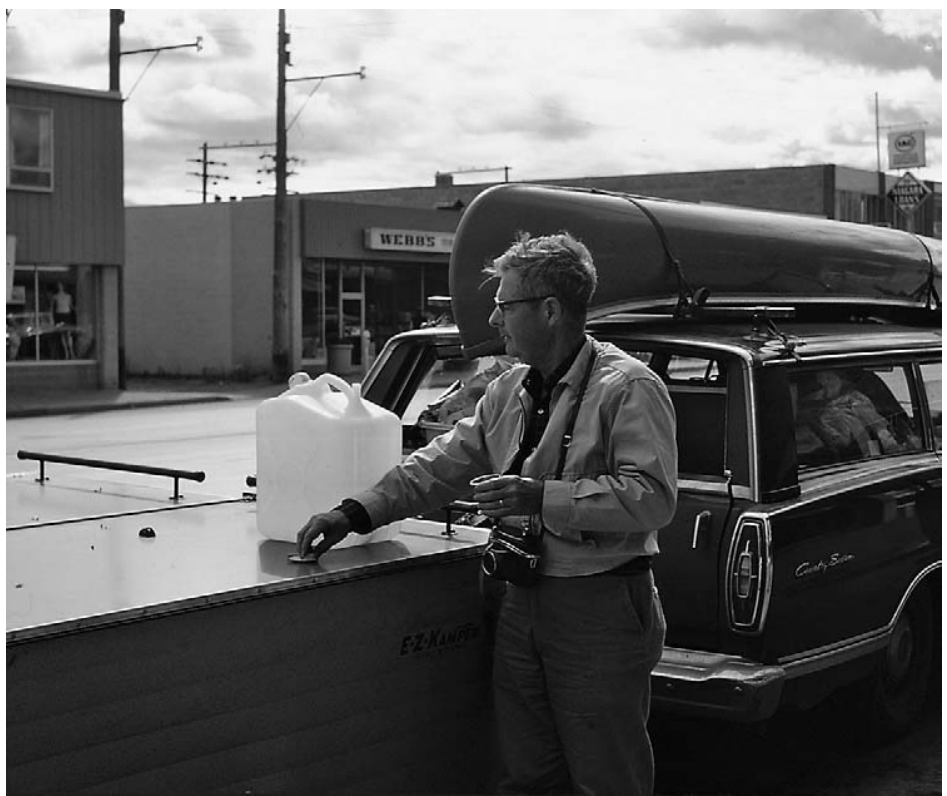

John ready to hit the road for an Alaska Highway lichen survey. Dawson Creek, B.C., Canada, July 1967. Photo T. Ahti.

One of the Grand Old Men (or 'Dean') of contemporary North American lichenology, John Walter Thomson, an emeritus professor in botany at the University of Wisconsin, passed away in his home at Mt. Horeb, Wisconsin, on 20 February 2009. He was 95 years old, born on 9 July 1913 in Cockenzie, Scotland. Not too many years ago he still identified lichens for his colleagues, and his last paper was published in 2007! He was lucky to be able to live at home up to the very end of his long lifetime, largely thanks to his not much younger wife Olive (they were married for nearly 72 years!).

Although originally a Scotsman, John Thomson was certainly American, having moved to the United States at the age of 8 in the 1920s with his family. As an undergraduate he studied at the Columbia University in New York, where he was much influenced by the local lichenologist Raymond Torrey, who died in 1938. Later, as a young scientist at the University of Wisconsin, Madison, his mentors included the aquatic plant specialist Norman Fassett and the renowned naturalist Aldo Leopold. His Ph.D. thesis on the origins of Wisconsin prairies (not on lichenology!) was completed in 1939. After a short stay back in New York he became a teacher at the State Teacher's college at Superior, Wisconsin, 1944, soon returning to the University of Wisconsin-Madison, serving there as Professor of Botany for the rest of his career (to 1984).

As a very friendly man John was even personally well known to virtually all North American lichenologists, and to many others all over the world. He had many prominent students who became leading lichenologists, such as Mason Hale, William Culberson, and Bruce McCune. The lichenologists Jan Looman, Herbert Sierk, William Jordan, 
Martin Lechowicz, and Mariette Cole were also his students. I myself visited his herbarium and home as a student for the first time in 1958, and ever since met him once in a while. In 1966 he came to Europe, spending over 6 months in Helsinki to study Arctic lichens in $\mathrm{Hb}$. Nylander and other collections. He also visited other important herbaria, such as Oslo to see Bernt Lynge's Greenland material. In 1967 John and I together with four family members had an expedition along the Alaska Highway from Alberta to Alaska and back to Wisconsin. I and my wife are enormously obliged to him for the great amount of lichenological and botanical knowledge and experience that we obtained through him during this journey. Our friendship continued even after I published a young man's unnecessarily critical review on his North American Cladonia book in The Bryologist in 1968!

That Alaska Highway trip was just one adventure to the Arctic and boreal backcountry areas that John made during his long career. He travelled and collected lichens in numerous places through much of Alaska, the Yukon, Northwest Territories, and Nunavut, in particular, making 14 major trips to those areas. We should remember that the Arctic and northern boreal areas offer extremely bleak conditions to do field work, not only due to frequently cold and wet weather and difficult terrain, but because hungry black flies and mosquitoes are your constant companions everywhere. You must also be ready to wander by foot for tremendous distances, since aircraft, helicopters and canoes cannot take you to every place. It is also prudent to carry a gun, because you may run into problems with bears or other animals. John Thomson was tough enough to stand these far northern conditions. In addition, you have to be able to raise money for such trips, since they can be very expensive.

As a result of his meticulous identification of thousands of lichen specimens collected by himself on his Arctic expeditions or sent to him by numerous other people, John finally published a mighty, really monumental, well-illustrated, two-volume handbook, American Arctic Lichens (1984, 1997). It was preceded by the book Lichens of the Alaskan Arctic Slope (1979). Before these he had published monographic treatments of North American Peltigera (1950), Cladonia (1968, '1967'), Physcia and allied genera (1963), and Baeomyces (1967), besides other major taxonomic or floristic treatments of many other genera, such as Rhizocarpon. Still, at the age of 89, Thomson published one more remarkable book, Lichens of Wisconsin (2003), based on almost a lifetime collecting in his home state. Numerous smaller floristic papers were also amongst his production of more than 100 publications. It was characteristic of Thomson that he attempted to cover all the major lichen groups, from macrolichens to the smallest crustose species. He described a number of new species, but usually paid more attention to the floristics and distributions of lichens. His numerous distribution maps in various papers have turned out to be extremely useful and stimulating even to lichenologists of other continents. He did not confine his studies to the Arctic, but travelled in several states of the USA, for example, California, Florida, Indiana, Oklahoma, New York, Pennsylvania, and Washington, writing articles on lichens in these areas. In addition to traditional herbarium taxonomy based on morphology he did apply methods of lichen chemistry. He was rather skillful in identifying substances using Asahina's crystal test method but also used thin-layer chromatography in his later years.

Thomson built up a highly valuable personal lichen herbarium at the University of Wisconsin, Madison, certainly the biggest collection of Arctic lichens in North America, but it contains large numbers of specimens from all over North America and also from other continents. Many ecologists, including George Scotter and Stephen Talbot in particular, sent him thousands of specimens from little known regions. His herbarium was recently incorporated into the university herbarium of WIS, making it one of the biggest lichen herbaria in North America.

In North American lichenology the period 1928-1952 has been called "the quiet years". 
There were then very few professional or even amateur lichenologists. It was at this very time when John Thomson was active and had students, and therefore became a central person in his field. He not only kept research on North American lichens alive but also essentially helped to inaugurate the modern period, characterized by such eminent lichenologists as Henry Imshaug, Mason Hale, William Culberson, I. Mackenzie Lamb (moved to the USA in 1954), and Vernon Ahmadjian.

John Thomson loved teaching. His course in plant taxonomy in Madison was very popular and greatly influenced not only students in biology but a great number of conservationists and through them hundreds of volunteers involved in natural area preservation. In fact, John and Olive showed passionate interests in local conservation ecology and were active in Citizens' Natural Resources Association, The Nature Conservancy and The Prairie Enthusiasts in Wisconsin. Southwest Wisconsin now has
636 acres of prairie lands named after the family, viz. the Thomson Memorial Prairie (to commemorate Douglas Thomson, one of their five children, who sadly died in 1978 at age 34, when he went to chase vandals from a railroad) south of Blue Mounds, and the Schorch-Thomson Prairie. In 1985 John and Olive received Gulf Oil Conservation Awards for their environmental activity. In 1985 John received the Gleason Award for his Arctic lichen manuals, and in 1992 he became an Acharius medalist. His work was also celebrated with a festschrift called Lichenographia Thomsoniana (1998), authored by many of his colleagues, students and friends.

John Thomson's research accomplishments and his professional services are immense. There is little doubt that he will be missed by everyone who had the pleasure of knowing him personally.

Teuvo Ahti 